\title{
Rural Women and Food Security: Diversification of Cassava-Based Foods in Gunungkidul District, Yogyakarta
}

\author{
Perempuan Desa dan Ketahanan Pangan: \\ Diversifikasi Pangan Berbasis Singkong di Kabupaten Gunungkidul, Yogyakarta
}

\author{
Suharko ${ }^{1, *}$ Bambang Hudayana ${ }^{2}$ \\ ${ }^{1}$ Department of Sociology and Center for Rural and Regional Development Studies, Gadjah Mada University \\ ${ }^{2}$ Department of Anthropology and Center for Rural and Regional Development Studies, Gadjah Mada University \\ ${ }^{*}$ E-mail: suharko@ugm.ac.id
}

\begin{abstract}
This article outlines the role of rural women in diversification of local foods in Indonesia, specifically cassava. Cassava is the third main staple food in Indonesia, after rice and corn. By referring to the concept of food security and food diversification, and using the case study method, this article describes and discusses rural women's innovations and business initiatives in developing nutritious processed cassava products in Gunungkidul Regency. These products are available at various outlets and are accessible and affordable to the public. Rural women have become the main actors in the diversification of local foods while also playing an important role in creating food security that has become a strategic agenda in Indonesia.
\end{abstract}

Key words: cassava, food diversification, food security, local food, women

\section{ABSTRAK}

Artikel ini memaparkan peran perempuan desa dalam diversifikasi pangan lokal di Indonesia, khususnya singkong atau ubi kayu. Singkong merupakan pangan pokok ketiga setelah beras dan jagung, dan telah dikonsumsi sejak lama oleh masyarakat Indonesia. Dengan merujuk pada konsep ketahanan pangan dan diversifikasi pangan, dan menggunakan metode studi kasus, artikel ini mendeskripsikan dan mendiskusikan prakarsa usaha dan inovasi dari para perempuan desa dalam mengembangkan produk-produk olahan makanan berbahan singkong yang bernutrisi di kabupaten Gunungkidul. Produk-produk ini tersedia di berbagai tempat penjualan, dan bisa diakses dengan mudah dan harganya terjangkau oleh warga masyarakat. Para perempuan desa telah menjadi pelaku utama dalam diversifikasi pangan lokal dan sekaligus berperan penting dalam menciptakan ketahanan pangan di Indonesia.

Kata Kunci: singkong, diversifikasi pangan, ketahanan pangan, pangan lokal, perempuan

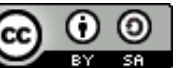

Content from this work may be used under the terms of the Creative Commons Attribution-ShareAlike 4.0 International License. Any further distributionof this work must maintain attribution to the author(s) and the title of the work, journal citation and DOI. 


\section{INTRODUCTION}

Women in developing countries have an important role in food security due to their roles in providing food for their households, both in the production and processing of local foods. The involvement of women has thus become increasingly important when food diversification is part of a strategic measure to achieve food security. The supply and availability of food from local sources is an important measure in ensuring national food security amidst the increasingly relentless penetration of the global food system (Lawrence, 2017).

In the context of Indonesia, a number of studies show that the dual role of women in domestic and public affairs is closely related to their role in maintaining food security at the household level. By utilizing home gardening, women have come up with additional food variations in order to achieve food security at the household level (Manoppo et al., 2018). Women also spend more time on domestic affairs including food preparation than men (Taridala et al., 2010). Rural housewives have significant roles in the production, procurement, preparation, processing, and securing quality of local foods; therefore, they are able to create food security at the household level (Poerwanto \& Supraja, 2016). The role of women in creating food security at the household level is apparent in households with female heads (Sasmita, 2011).

The findings of the above studies confirm the significant role of women in household food security. In Asian nations, women spend a lot of time as "caretakers" with tasks such as food preparation that requires an average of 1 hour and 45 minutes of their time each day and cleaning up that takes an average of 45 minutes a day. Therefore, women are the main actors in the food chain (Mathur, 2011). In Bangladesh, rural women were engaged in a homestead gardening program where they established home gardens. The program, which was supported by NGOs, has increased availability, access to and utilization of food from their gardens (especially vegetables and fruit), improved their nutrition, and ensured household food security (Bushamuka et al., 2005).

These studies still limit the role of women to the domain of domestic affairs, which is generally ascribed to women in patriarchal societies. However, Luna (2013) and Suharko (2019) indicate that rural women have now moved out of the domestic domain and entered the public sector through initiatives of diversifying local foods. In order to provide a specific overview of the strategic role of women in food security, this article will address the question: to what extent do women's role and their involvement in the diversification of local food support food security at the local level? This article will demonstrate rural women's engagement and contribution in the diversification of local foods made from cassava (Manihot utilissima or Manihot esculenta crantz) in Gunungkidul district.

In the Indonesian context, local food diversification initiatives are a strategic necessity due to two reasons. First, most Indonesians nowadays rely on a single staple food, namely rice, although 11 Indonesian basic food staples have been identified across the Archipelago. Over time, staple food consumption patterns shifted from a diverse range of local staple foods including cassava, sago, corn, and various tubers to rice. Consequently, production and consumption of local foods have decreased, and as of late 1980s, Indonesians relied on rice as the main commodity for staple food (Ariani et al., 2013). At the same time, food products made from local resources developed an image of being inferior. Consuming products made from local foods is synonymous to being poor (Sutrisno \& Edris, 2009).

Second, more Indonesians have preference for wheat-based food products, whereas wheat is not being produced in Indonesia. The National Socio-Economic Survey Data (Susenas) shows that the national participation rate of wheat consumption (including derivatives) was $87.2 \%$ in 2014 and $92.4 \%$ in urban populations. Wheat imports have continued to increase from 7.48 million tons in 2015 to 8.1 million tons in 2016. Indonesia is the world's second largest wheat importer after Egypt (Ariani, 2016). For these two reasons, Indonesian food security is vulnerable (Rahardi, 2018). 


\section{Conceptual Framework: Food Security, Food Diversification and Women}

The concept of food security has evolved since the 1970s. Initially, the concept focused on food availability. However, along with the development of food issues, this definition has continued to change. Eventually, as a reference and based on international agreement, the Food and Agriculture Organization (FAO) clarified the definition of food security in The State of Food Insecurity 2001 as:

a situation that exists when all people at all times have physical, social and economic access to sufficient, safe and nutritious food that meets their dietary needs for an active and healthy life (Le et. al, 2015: 1).

There are four dimensions to food security in this definition: first, food availability or a sufficient amount of food for distribution to citizens; second, stability of supply, namely the availability of sufficient food supply at all times; third, food access or affordability, namely the ability to obtain food that is available locally and in markets; and fourth, food utilization or consumption that meets dietary requirements for an active and healthy life. Food security is part of the rights to food (Hadiprayitno, 2010) that can only be achieved when all of these dimensions are functioning simultaneously.

Indonesia has adopted this food security definition and its dimensions through Food Law No. $18 / 2012$. In a slightly different formula, food security in reference to article 1 , in this Law is when "food requirements for the state through to the individual are met, which is reflected in sufficient food availability, in terms of quantity and quality, safety, diversity, nutrition, equity, and affordability and does not conflict with the religion, beliefs or culture of a community to be able to live a healthy, active, and productive life in a sustainable manner" (Law on Food No.18/2012, 2012). The realization of food security is a necessary condition for the development of human resources which is one of the priorities of national development.

Food diversification can be understood in terms of effort to create availability of adequate amounts and greater variety of nutritious foods (FAO 1997). In the context of Indonesia, in reference to the Food Law No.18/2012, food diversification is "an endeavor to increase the availability of diverse foods that are based on the potential of local resources". Increasing food availability can be achieved by diversifying production through the development of various food commodities, and diversification in post-harvest by processing and developing various food products from one type of commodity (Rachmat \& Syakir, 2016).

Food diversification is often linked to endeavors in diversifying consumption of non-rice carbohydrates by further utilizing local food sources that are still seldom used (Ariani et al., 2013). This can be accomplished by encouraging small and medium enterprises, food businesses, and the private sector to develop and provide carbohydrate-based food products that are varied and locally sourced (Budijanto \& Yuliana, 2015). With the availability of alternative non-rice foods, dependency on certain types of foods (rice) can be reduced. This also provides communities with a variety of food choices in terms of staple foods and complementary/supplementary foods (Rachmat \& Syakir, 2016).

Food diversification enables people to maintain a diverse, nutritionally balanced, and safe food consumption, which is the foundation for improving quality of life. As such, food diversification encompasses three interrelated matters: (a) action to provide diverse foods; (b) foods coming from local resources; and (c) as an indication that people are able to uphold diverse food consumption patterns, in terms of staple and supplementary foods. In this regard, food diversification is clearly a method to achieve food security (Law on Food No.18/2012, article 130).

Women have a significant role in supporting food security through food diversification. Women who are engaged in their household economy contribute to food production and ultimately play a role in food security (Kotzé, 2003). Women in rural areas across Asia and the Pacific region play a critical role in supporting food security. However, the role of women in food security generally are undervalued (Balakrishnan et al., 2005; Quisumbing et al., 1998). Government policies to carry out food diversification, such as Government Regulation (PP) No. 17/2015 on Food Security and Nutrition 
and Presidential Regulation No. 22/2009 on the Policy for the Acceleration of Diversification of Local Resource-Based Food Consumption, does not specifically mention the role of women.

Referring to PP No.17/2015 (Articles 25 \& 26), one of the efforts to diversify food is through "strengthening micro, small and medium enterprises in the food sector." In this regard, as in many other countries, women in Indonesia are generally involved in micro and small enterprises. Japtha et al. (2016) showed that $52.9 \%$ of micro enterprises, $50.6 \%$ of small enterprises and $34.0 \%$ of medium enterprises in urban areas are owned by women. Women primarily run these enterprises in order to support their households and to meet their own development needs.

The role of women in creating food security shows the importance of women's involvement in development. Since the 1990s, the governments, donor agencies, and non-government organizations (NGOs) have been promoting the concept of Gender and Development (GAD) as a basis for reference in women's empowerment programs. GAD places women as actors of change, not merely as passive objects in development. Women can work in productive and reproductive sectors on an equal basis with men (Mosse, 1993). The GAD approach through gender mainstreaming is continuously promoted as a basic principle of the formulation and implementation of development programs, including food security in Indonesia.

\section{RESEARCH METHOD}

This research used a case study (Creswell \& Poth, 2018). This case study is focused on a particular issue, namely the role of rural women in the diversification of cassava-based foods in Gunungkidul district.

Cassava is a strategic food as it is a source of carbohydrates in Indonesia, particularly for those living in dry regions in Java, Sumatra and Sulawesi as both a staple and supplementary food (Supriadi, 2005). With the increasing consumption of rice as the dominant staple for almost the entire population of Indonesia, the availability and consumption of foods made from cassava has diminished since the late 1980s. In Paliyan sub-district in Gunungkidul, Suratiyah et al. (2013) shows that $99.4 \%$ of farmers households have switched to consuming rice throughout the year. However, women are still engaged in cassava diversification practices in the Gunungkidul district (Dewi, 2013).

Gunungkidul district is on the southern side of the island of Java in Indonesia. It covers $1,485.36$ ha and is the largest area compared to other districts and cities in the Yogyakarta province. According to the Population Census, the district's population continued to grow from 670,433 in 2000 to 675,382 in 2010 and then 729,364 in 2017 . The average population growth rate is around 1.06 percent per year. There is a high percentage of poor people in the district, which exceeds the national average. Between 2013 to 2017 , the number of the poor fluctuated from $21.70 \%$ to $20.83 \%$ to $21.73 \%$, to $19.34 \%$ and then to $18.65 \%$ respectively (Agency of Statistics Gunung Kidul, 2018).

Almost all agricultural land in Gunungkidul district is dry land and depends on rainfall. Farmers are compelled to use their land carefully as they must adapt to the rainy season in order to maximize food production. Common crops grown in this area are those that do not require much water such as cassava, corn, peanuts, and upland rice.

Cassava plants can be cultivated on dry land, in home garden and even on degraded land in Gunungkidul. The vast majority of agricultural land in the district is planted with cassava with a harvest area that covered 49,487 Ha in 2017 (Agency of Statistics Gunung Kidul, 2018) Cassava production may reach to 900,000 tons per year, making this district the largest cassava producer on the island of Java (Faidah, 2017). The local population has been consuming cassava as a main staple for a very long time and has developed into a production center processing cassava-based food product.

This research's primary data collection was conducted in March-July in 2015 through observation, interviews, and focus group discussions (FGD). The FGD informants and participants 
were rural women who own-enterprises processing products made from cassava in Ngawu and Semin villages. These two villages have developed into production centers processing cassava-based food products. As for statistical data and other secondary data references, the most up-to-date data was used from credible online sources. An analysis of themes was conducted in order to understand the complexity of the cases (Stake 1995). Based on this analysis, this article reveals the role of rural women in the diversification of local foods.

\section{RESULTS AND DISCUSSION}

\section{Diversification of Cassava-based Foods}

Gunungkidul communities have been processing and consuming cassava for a long time. In general, cassava can be harvested at age of 8-10 months. Households usually process the fresh cassava yields into everyday foods, preserve it as food reserves, or sell it to nearby markets. In practice, households tend to share fresh cassava with each other. If households do not have it, they can borrow or buy it from one another.

Fresh cassava is generally traded at markets. Various types of cassava are available at markets. The preferred types of cassava, which are often used as a raw material in processed foods are the mertego (butter) and ketan (glutinous rice) species. The mertego cassava flesh is yellowish in color with a sweet, butter-like flavor chewy. Food products processed from this type of cassava have an appetizing color. The ketan cassava flesh is white with dense and glutinous taste.

Women throughout the district generally process harvested cassava by boiling or frying it for their daily consumption but they often mix it with an array of other ingredients (particularly grated coconut, coconut sugar, rice flour, and bananas) to become various snack foods, such as getuk ( steamed cassava that is crushed and mixed with sugar), lemet (a steamed grated cassava with palm sugar wrapped in banana leaves), cemplon (grated cassava that is filled with palm sugar and then fried), combro ( grated cassava filled with a chili tempe filling and fried), and sawut (grated cassava mixed with palm sugar that is then steamed and sprinkled with grated coconut on top). Fresh cassava is also processed into dry foods, such as cassava shavings, cassava chips, cassava sticks, cassava crackers (lanting), crunchy cassava (opak), or fermented (tape) for longer storage life.

Cassava is also commonly sun-dried and referred to as gaplek (made from crushed cassava that is dried and used as an ingredient in other foods). Gaplek is usually stored as a food reserve but is also sold at markets. Women process gaplek into a variety of foods, in particular gatot (a variant of gaplek that is colored black) and thiwul (a rice substitute made from gaplek). These are common household foods and are also sold to consumers. A number of women entrepreneurs have further innovated these products by drying them to produce instant gatot and thiwul, which have a long shelf life and can be cooked quickly.

This method of cooking and processing fresh cassava has always been practiced and passed down from generation to generation. In the past, before rice was the main staple food, most people processed fresh cassava as their staple food and also as a snack. Nowadays, cassava-based processed foods tend to become supplementary foods or snacks only. The variety of foods processed from fresh cassava add to the availability, quantity and types of food that can be consumed by the public.

Opportunities to create unique tasting food products are now vast with the technology to make modified cassava flour (mocaf). Mocaf is made from cassava that has been modified through a fermentation process using microbes. This technology has made it easier to process fresh cassava into preserved products, in the forms of mocaf and tapioca flour or starch. Mocaf is made from cassava pulp that is fermented, dried and then ground, while tapioca flour is made from cassava starch extract. As cassava cannot be stored for long, processing it into flour facilitates storage and allows further 
processing. These two types of cassava flours are supplied and sold by a number of entrepreneurs, some of whom are women.

Tapioca starch can be processed into wet and dry food products, such as cassava doughnuts, klepon (a variant of small tapioca flour balls that are filled with palm sugar, then sprinkled with grated coconut), geblek (made from tapioca starch that is mixed with garlic and fried), patilo (crackers made from starch) and various other sweet snacks. Mocaf can be processed into various dry and wet food products. Mocaf is readily available, and thus has attracted the interest of many women, including housewives and food producers to innovate and produce a range of mocaf products. Manufacturers have processed mocaf into various consumable products that are usually mixed with wheat or rice flour such as noodles, cassava coconut cakes, and putu ayu (made from mocaf mixed with eggs, sugar and grated coconut that is then steamed).

Mocaf has even been processed to make instant noodles, through an innovative process. Dry processed products have an advantage over wet-processed products in terms of durability. Fresh products can last for around a week, while instant products and flours can last for up to one year.

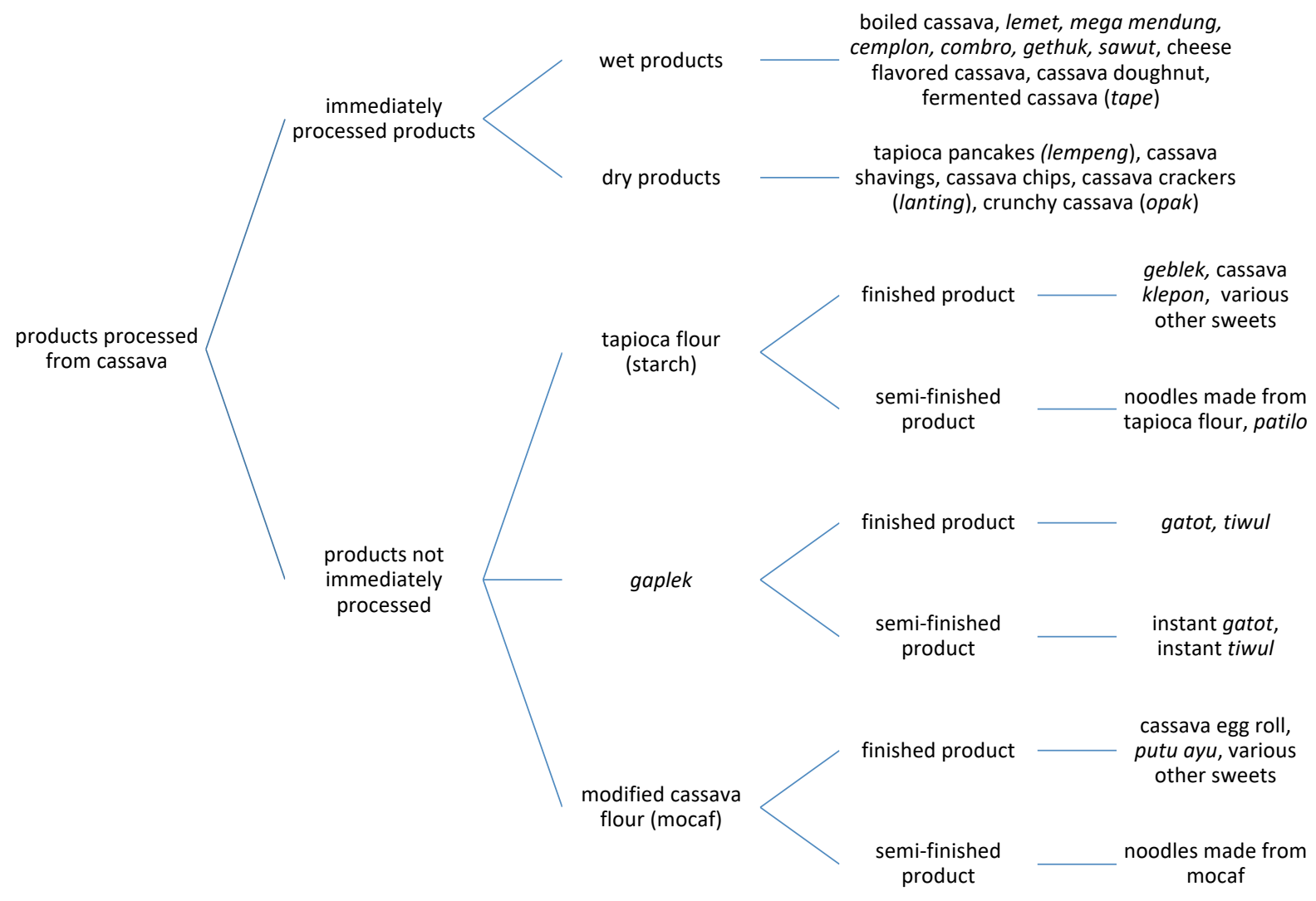

Source: field data

Figure 1. Variations of cassava based processed foods in Gunungkidul district 


\section{The Nutritional Value and Benefits of Cassava-based Foods}

The nutritional value of cassava is very good. According to the Indonesian Ministry of Agriculture (2017) 100 grams of cassava contains $154 \mathrm{kcal}$ of energy, 1 gram of protein, 0.3 grams of fat, 36.8 grams of carbohydrates, $31 \mathrm{mg}$ of vitamin C, $1.1 \mathrm{mg}$ of iron, $77 \mathrm{mg}$ of calcium, and 0.9 grams of fiber. For comparison, 100 grams of maize contains $366 \mathrm{kcal}$ of energy, 9.8 gram of protein, 7.3 grams of fat, 69.1 grams of carbohydrates, $3 \mathrm{mg}$ of vitamin C, $2.3 \mathrm{mg}$ of iron, $30 \mathrm{mg}$ of calcium, and 2.2 grams of fiber.

Cassava is an excellent source of carbohydrates as it has a high carbohydrate content. It also has only half the calories of rice (staple food) and therefore is highly suitable to be consumed on a regular basis. cassava is also a good source of dietary fiber, although the protein content is low. Cassava is a healthy food based on its nutritional value and regular consumption can control blood pressure, thus making it an alternative staple for people with high blood pressure. The natural antioxidant compounds present in cassava are beneficial to blood circulation. Therefore, cassava is a staple food after rice and maize (Masniah \& Yusuf, 2013).

Cassava has a low glycemic index (GI) meaning a low glucose content (Masniah \& Yusuf, 2013). For those who need to reduce their sugar intake (due to diabetes) or who want to choose a healthy lifestyle, processed cassava-based foods are a good option to replace rice, or at least as an additional staple food option.

Cassava is gluten-free, therefore, it is safe for people with allergies to wheat, or anyone suffering from rheumatoid arthritis, Celiac disease and Crohn's disease (Ministry of Agriculture 2017). Cassava is also a good food source for people with autism as it does not trigger allergies or hypersensitivity (Herminiati, 2009). It is for this reason that cassava flour is often sought after for family members who have autism.

Although cassava is healthy in terms of its nutritional value, it is difficult to find research results demonstrating the changes that occur to the nutritional content of cassava once it has been processed into products. The processing of cassava into ready-made products, such as cassava instant noodles, will certainly change the nutritional content. However, small enterprises that produce instant noodles made from cassava claim that because the nutritional content of cassava is good then naturally their products are very healthy (Kabarhandayani.com, 2016).

\section{Women's Engagement in the Diversification of Cassava-based Foods}

Women in Gunungkidul district do not only manage the food in their households but are also engaged in economic ventures related to processing cassava resources. A number of women entrepreneurs and women's groups run home industries processing and producing an array of cassavabased food products. They have even developed a cassava food processing industry in the form of home industries and enterprise groups. Following is a brief overview of four enterprises that have achieved prominent innovation in diversifying cassava-based products. They include two micro enterprises and two small enterprise groups.

1. Ms. Yuni (51 years), an entrepreneur in Ngawu village in Gunungkidul. She has innovated with new products made from cassava, namely dawet made from mocaf. She obtained Mocaf which is produced by the growing home industries in this district.

This innovation was born out of her strong desire to create new products. Previously, cassava was only processed into traditional foods that did not have much value economically. Ms. Yuni experimented through trial and error until she finally produced the mocaf dawet product. Unlike traditional dawet, which is generally made from rice flour, she makes dawet from mocaf and consumers have welcomed her new product. 
Starting from a mocaf dawet outlet, she then successfully opened several mocaf dawet outlets in strategic locations in Playen sub-district. Income earned from these outlets has improved the quality of life of her family. As seen in the name of her product, "unique Gunungkidul iced dawet made from mocaf ", she has continued to develop her home industry and hopes that it may become an icon in Gunungkidul district.

2. Ms. Kartumi (55 years) from Semin village in Gunungkidul came up with an innovative product processed from cassava in the form of cassava peel chips. Cassava peel is usually used as animal feed, or even thrown away. Through trial and error, Ms. Kartumi successfully processed cassava peel into a dry food.

She obtained raw materials from cassava farmers and village markets. She created her product by mixing the peel with wheat flour and other ingredients. She has designed interesting packaging for her product, which is sold at food outlets. In addition, she has also customized cassava sticks that are made by other processed food enterprises by adding other ingredients to the batter, such as jackfruit, cheese, and chili to produce a variety of flavored sticks.

She sold the products by cooperating in sales with food stalls, kiosks and souvenir shops that grow in Gunungkidul along with the growth of tourist destinations. These innovative products have been popular with consumers, which is evident in her orders that continue to increase.

3. The Barokah Enterprise Group in Semin village. This enterprise group that produces processed cassava originated from the Mayangsari Women Farmers Group (Kelompok Wanita Tani - KWT). KWT was established by the government in order to involve women farmers in ventures to increase agricultural production. The KWT members were dissatisfied with agricultural production activities that has no impact on increasing household income. They then took the initiative to try processing foods from cassava independently, invited experienced trainers and requested the village government to support this initiative.

They produced a new product by processing gaplek into instant tiwul and instant gatot. Traditional tiwul and gatot are wet foods that generally deteriorate quickly as they only last 1-2 days. These instant processed food products can be stored for a long time and are easily cooked and served. Both of these products were first marketed in 2005. In addition to these two products, the KWT group also produces cassava sticks, wonton chips, and doughnuts. These are all premium products from this group.

The KWT members established the Barokah enterprise group to continue their food processing venture. This enterprise has become a platform for its members to develop and produce processed foods and market them to a wider consumer base. The Barokah enterprise group actively markets its products to kiosks, food stalls and souvenir shops around the Gunungkidul region so that they are accessible to consumers and visiting tourists.

The group has developed a management structure and has a clear division of labor among members in order for the enterprise to run smoothly. Regular monthly meetings are held to enhance solidarity, coordinate marketing, share profits, and conduct savings and loans activities. This has enabled women in the enterprise to develop diversification of cassava-based foods and simultaneously increase their household income.

4. The P-21 enterprise group. The P-21 enterprise group (Putri 21, consisting of 21 women) was established in the late 1980s. This group was formed out of a government training program on processing local foods. Initially, P-21 was processing melinjo (Gnetum gnemon) seeds which were readily available in Ngawu village. However, as melinjo seeds became scarce, P-21 switched to producing bananas chips and other foods from sources easily obtained in their village.

Once Ms. Suti became the P-21 chairperson, the enterprise became increasingly able to develop its food processing enterprise. Local government, financial institutions, NGOs, companies and universities have provided training and mentoring to P-21. The P-21 group also cooperates with 
traders to sell their processed products, that is, wet foods made from raw cassava, such as tiwul, gatot, gethuk, and lemet.

The P-21 group's knowledge, skills and experience in processing foods from local resources was the reason for establishing the Putri 21 Self-reliant Rural Farming Training Center (P4S) in 2006. This training center offers internships to women who want to learn about food processing. Participants come from various regions in Sumatra, Kalimantan, Sulawesi and Papua. The training center also holds training in various other regions by request.

The P-21 enterprise group continues to innovate and produce excellent quality products. Up until 2015, P-21 produced 30 different types of processed foods from local resources, namely cassava, tubers, legumes and bananas. The two main products of P-21 are mocaf and noodles made from this flour, which are very popular with the upper middle class in urban areas. In recognition of the trainings and the innovative products made from local foods, the P-21 chairperson received a food security award from the Indonesian government in 2012 in the culinary category at the Indonesian Archipelago Food Awards.

\section{Discussion}

Rural women in Gunungkidul district have long been involved in the diversification of cassavabased foods. They are involved in the production process of raw materials, harvesting, preserving, processing and also preparing food on a daily basis. Although rice has become the main staple food, women continue to work on processing and preparing various cassava-based products in their respective households. In this way, rice consumption has not completely eliminated cassava as a staple food. What has followed is the consumption of a combination of staple foods, namely rice and cassava. The availability of various processed cassava-based foods adds variation to household foods and sources of nutrition.

In addition to providing and processing a variety of foods for their own households, a number of women entrepreneurs and women's enterprise groups run home industries processing and producing an array of cassava-based food products. Enterprises processing cassava-based foods are able to innovate and produce quality contemporary products. In this respect, processed cassava-based products have succeeded in changing the image of cassava as an inferior and unacceptable food source. Various processed cassava-based products have become increasingly available at outlets around Gunungkidul and have even began to be distributed to other regions outside of the district. Thus, people are able to access processed cassava-based products easily and integrate them into their daily diet.

The wide availability of diverse cassava-based products means that they are an alternative food or an additional choice to menus. Modern and industrial cassava-based food processing innovations in terms of form and packaging, such as instant tiwul, instant gatot, instant noodles made from mocaf, cassava brownies and various flavored cassava sticks, have been able to transcend the image of cassava as a poor quality and unhealthy food. These product innovations have paved the way for cassava to now be a popular product that is widely consumed. Cassava is still considered to be a staple food, aside from rice for farmers in Gunungkidul. Farmers usually consume foods processed from cassava in the morning before leaving for work in the fields, and then eat rice at lunchtime.

Diversification and availability of cassava-based products, to some extent, can contribute to addressing two problems that threaten food security, especially at the local level. Food products produced from tapioca flour and gaplek can be a dietary choice from rice as staple food. The Gunungkidul people have actually consumed gatot and tiwul for a long time, and even that food has become one of the characteristics of the local food culture. But the dominance of rice and wheat has reduced consumption of cassava as local staple foods. The development of new processed food 
products, such as instant gatot and instant tiwul, which indicates the development of modernizing food systems (Lawrence, 2017), can encourage people to consume local food again as staple food.

While food products produced by mocaf can be a dietary choice of food products made from wheat flour, Mocaf cannot completely replace wheat flavor. But if the consumption of mocaf increases, then it can reduce wheat imports which tend to continue to increase (Ariani, 2016). It really depends on the government policy to support the expansion of mocaf consumption. Many micro and small enterprises have been able to produce mocaf in a number of regions, but generally the production capacity and marketing scope are still limited.

Diversification of cassava-based foods in Gunungkidul has not been able to significantly reduce the consumption of rice or processed foods made from wheat flour. Food diversification might only increase the availability and choices of local processed food products. With the availability of various processed cassava foods, there is a wide selection of staple foods and snacks to meet dietary needs and lead to healthier lifestyles.

Variations in cassava-based processed foods, including production practices that have been passed down from generation to generation as well as those developed through innovative means, show that the diversification of local foods has long been active in Gunungkidul district. Local food diversification practices have even become an inherent part of small micro and medium enterprise developments, which are driven by women.

A number of supporting factors have contributed to the diversification of local food practices, which simultaneously increases food security at the regional level. Government policy and commitment is generally a key factor in food diversification. Indonesia's national government indeed appears to have failed in implementing various food diversification policies and programs. However, in contrast, at the regional level the Gunungkidul local government has taken positive action. In line with the implementation of the regional autonomy policy, the Gunungkidul local government has clearly continued to support ventures diversifying local food resources (Hudayana, 2016).

Field data confirms that the emergence of cassava-based food processing enterprises, in part, is the result of various food processing, packing, promotion and marketing training programs initiated by the local government. The majority of cassava-based processing enterprises run by women in Ngawu and Semin villages were initiated after training was provided by the Agriculture Service. The local government has also involved these enterprises in processed food production exhibitions held at both the regional and provincial levels and continues to support them to participate in cassava-based product competitions. In May in 2015, the Gunungkidul government held "farmers markets" in Ngawu and Semin villages involving these women's enterprises.

In terms of capital, enterprises that process food have relatively good access to micro credit and banking institutions. As micro or household scale cassava-based food processing enterprises do not require large amounts of capital, they generally do not need loans. However, if an enterprise gets any bigger, then it will require additional capital. The women's enterprises in Ngawu and Semin villages can access credit facilities provided by savings and credit groups, or cooperatives and banks if they need additional capital to develop their enterprises.

Women are mobilized through group organizing in developing food processing enterprises. Training provided by the government usually encourages women to develop economic enterprises in groups rather than individually. By revitalizing already established women's groups or by forming new enterprise groups, mutual learning and collaboration takes place to further develop enterprises. Through the enterprise group platform, any difficulties in obtaining a continuous supply of raw materials can be resolved by collaborating with cassava farmer groups around or even outside of the Gunungkidul region. Likewise, they are also able to manage the need for additional workers if product orders increase. Collaboration between group members also allows them to innovate and market their 
products. It is also easier to access to assistance and support from the government, universities, and credit or banking institutions through enterprise groups. The development and success of the "Barokah" and "P-21" enterprise groups evidently confirms this.

The progress achieved by these cassava-based food processing enterprises thus far indicates that there is potential for them to continue to diversify foods through product innovation, improve product quality and reach broader markets. This is compatible with the trend of increased awareness and healthy lifestyle practices, especially among the middle and upper-class stratums. Cassava is nongluten and has a low glucose content (Masniah \& Yusuf, 2013). For those who need to reduce their sugar intake (due to diabetes) or who want to choose a healthy lifestyle, processed cassava-based foods are a good option to replace rice, or at least as an additional staple food option. This highlights the fact that the diversification of cassava-based foods goes hand in hand with the trend of changing people's lifestyles to consume varied and healthy foods.

Nevertheless, there are some serious challenges in sustaining diversification of local cassavabased foods in the future. This is due to the basic nature of cassava itself. Although mocaf and tapioca flour can be used in various types of popular foods, due to their non-gluten nature, a certain ratio of other ingredients must be used with them in processed foods. Mocaf usually needs to be mixed with wheat and rice flours in order to produce a variety of higher quality processed products. Additionally, mocaf is not commonly used at the household level. As it is not yet been widely distributed, it is relatively expensive compared to wheat flour, which is easily available. Despite being an imported good, wheat flour continues to be more popular and is the choice of flour for the vast majority of the community. Thus, prices of processed cassava foods, although still affordable to the general public, tend to be more expensive than other wheat based processed food products. For example, instant noodles made from mocaf are more expensive than instant noodles made from wheat flour, which are notably popular in the community.

Moreover, in terms of taste, products that are directly processed from cassava are less tasty than products made from rice and wheat flour derivatives, especially instant noodles (Ariani et al., 2013). As often seen in mass media advertising, instant noodles are promoted as a nutritious and practical food. They are cheap and readily available and therefore very accessible to the public. In this light, it's not difficult to understand why people tend to be reluctant to consume cassava and other processed local food products, as they have long been consuming rice as a staple food and instant noodles have become extremely popular.

In line with rice becoming the dominant staple food, there is still a stigma that consuming products made from cassava is identical with being poor. Cassava was indeed the staple food of poor families in the past. Tiwul, which was once the main staple food source for people in Gunungkidul has been replaced with rice. Many Gunungkidul residents are reluctant to consume cassava due to the social stigma.

The involvement of women in food diversification has also become a trend that occurs in numerous localities in Indonesia. Although in difficult circumstances like poverty, social conflict, and disasters, they are able to produce, process and supply various types of local foods for household and public consumption and even sell them as home industry products. Oxfam Indonesia refers to these women as 'female food heroes' (Anwar, 2018). The accomplishment of these women in providing these food products allows communities to consume a diverse range of local foods and can actually create food security at the local level.

\section{CONCLUSION}

Practices diversifying cassava-based foods continue to develop in Gunungkidul district. Traditional household cassava processing practices and modern food processing industries produce an array of processed foods that contain high nutritional value. These food products are readily available 
at outlets and affordable to the general public. The variation of these cassava-based processed products adds to the availability of high-quality local foods. The public has numerous choices of processed foods to meet their daily nutritional needs. Thus, diversification of local food is able to strengthen food security at the local level.

It is rural women who have become an important role in diversifying local food. These women have established micro and small enterprises that process and produce varied and nutritious cassavabased products. They have even been able to combine traditional knowledge and practices with modern practices in processing local foods. This is evident in new products produced from cassava using food processing innovations. These women in Gunungkidul are a part of a number of local communities in various countries that have contributed to reviving local food systems, while simultaneously increasing food security.

Gunungkidul is an example of a region that has been able to diversify local cassava-based foods as a way to create food security at the local level. Local governments have a commitment and develop women's empowerment programs based on the development of local food diversification. This district is a good example for other regions with abundant local food sources that could replicate these practices. Development of local food diversification to support food security can be achieved with support and facilitation from the government, NGOs, universities, financial institutions and banks, and other food stakeholders.

\section{ACKNOWLEDGEMENTS}

Many thanks and appreciation to the research assistants: M. Yunan Roniardian, D.C. Mulyono, and Dyah Candra Dewi for data collection and analysis during the research process.

\section{REFERENCES}

Agency of Statistics Gunung Kidul. (2018). Kabupaten Gunungkidul Dalam Angka 2018 (Gunungkidul District in the 2018 Figures). Agency of Statistics Indonesia (BPS).

Anwar, K. (2018, December). Bernadete Deram: Berdayakan Kembali Pangan Lokal (Re-empowering Local Foods). Kompas (Printed), 12.

Ariani, M. (2016). Pergeseran Konsumsi Pangan Lokal, Suatu Keprihatinan (Shifting Consumption of Local Foods, a Matter of Concern). In E. Pasandaran, R. Heriawan, \& M. Syakir (Eds.), Pangan Lokal: Budaya, Potensi dan Prospek Pengembangan (Local Food: Culture, Potential and Development Prospects). IAARD Press.

Ariani, M., Hermanto, Hardono, G. S., Sugiarto, \& Wahyudi, T. S. (2013). Kajian Strategi Pengembangan Diversifikasi Pangan Lokal (Local Food Diversification Development Strategies Study). http://pse.litbang.pertanian.go.id/ind/pdffiles/anjak_2013_06.pdf

Badan Ketahanan Pangan (Agency of Food Security Republic of Indonesia). (2017, May). Pangan Lokal - Informasi Gizi. Ministry of Agriculture Republic of Indonesia. http://pangannusantara.bkp.pertanian.go.id/?show=page\&act=view\&id=16\&title=Informasi Gizi

Balakrishnan, R., Budijanto, S., Yuliana, N. D., Bushamuka, V. N., de Pee, S., Talukder, A., Kiess, L., Panagides, D., Taher, A., Bloem, M., Creswell, J. W., \& Poth, C. N. (2005). Rural women and food security in Asia and the Pacific: Prospects and paradoxes. Journal of Developments in Sustainable Agriculture, 26(1), 7-14. https://doi.org/10.1177/156482650502600102

Budijanto, S., \& Yuliana, N. D. (2015). Development of Rice Analog as a Food Diversification Vehicle in Indonesia. Journal of Developments in Sustainable Agriculture, 10, 7-14.

Bushamuka, V. N., de Pee, S., Talukder, A., Kiess, L., Panagides, D., Taher, A., \& Bloem, M. (2005). Impact of a Homestead Gardening Program on Household Food Security and Empowerment of 
Women in Bangladesh. Food and Nutrition Bulletin, 26(1), 17-25. https://doi.org/10.1177/156482650502600102

Creswell, J. W., \& Poth, C. N. (2018). Qualitative Inquiry and Research Design: Choosing Among Five Approaches (4th ed.). SAGE Publications.

Dewi, Y. P. (2013). Strategi Pengembangan Sentra Industri Krecek Singkong Di Kecamatan Ponjong Kabupaten Gunungkidul (Development Strategies for Cassava Cracker Industry Centers in Ponjong Sub-district in Gunungkidul District). Undergraduate Thesis. Universitas Sebelas Maret.

Faidah, T. (2017, May). Harga Jual Singkong Rendah, Pemerintah Olah Produk Jadi Beras Mokaf. Sorot.Co. https://gunungkidul.sorot.co/berita-91881-link-.html

Hadiprayitno, I. I. (2010). Food Security and Human Rights in Indonesia. Development in Practice, $20(1), 122-130$.

Herminiati, A. (2009). Diet Makanan untuk Penyandang Autis (Food for People with Autism). Jurnal Pangan, 18(2), 90-95. https://doi.org/10.33964/jp.v18i4.216

Hudayana, B. (2016). Empowering Rural Women in Java Through Cassava Culinary Business in the Reform Era. The 7th Rural Research and Planning Group (RRPG7) International Conference and Field Study in Kuala Lumpur. Universiti Teknologi Malaysia.

Japtha, R., Murthy, P., Fahmi, Y., Marina, A., \& Gupta, A. (2016). Women-owned SMEs in Indonesia : a golden opportunity for local financial institutions : UKM yang dimiliki wanita di Indonesia: kesempatan emas untuk institusi keuangan lokal (Bahasa (Indonesian). World Bank Group.

Kabarhandayani.com. (2016, May). Mie Ayo, Mi Instan Berbahan Singkong Asal Gunungkidul Penuh Gizi. kabarhandayani.com. https://kabarhandayani.com/mie-ayo-mi-instan-berbahan-singkongasal-gunungkidul-penuh-gizi/

Kotzé, D. A. (2003). Role of Women in the Household Economy, Food Production and Food Security: Policy Guidelines. Outlook on Agriculture, 32(2), 111-121. https://doi.org/10.5367/000000003101294352

Lawrence, G. (2017). Re-evaluating food systems and food security: A global perspective. Journal of Sociology, 53(4), 774-796. https://doi.org/10.1177/1440783317743678

Luna, A. P. P. (2013). Neoliberalism and Women's Struggle for Food Security in Tlaucingo. Latin American Perspectives, 40(5), 93-104. https://doi.org/10.1177/0094582X13496387

Manoppo, C. N., Amanah, S., Asngari, P. S., \& Tjitropranoto, P. (2018). Women Competence on Home Gardening to Support Food Diversification. Pertanika Journal of Social Sciences \& Humanities, 26(2), 825-840.

Masniah, \& Yusuf. (2013). Potensi Ubi Kayu sebagai Pangan Fungsional (Potential of cassava as a functional food). The Seminar on Research Results of Various Legume and Tuber Crops. Jakarta, Indonesia.

Mathur, A. (2011). Women and Food Security: A Comparison of South Asia and Southeast Asia. South Asian Survey, 18(2), 181-206. https://doi.org/10.1177/0971523113513373

Law on Food No.18/2012, (2012).

Mosse, J. C. (1993). Half the World, Half a Chance: An introduction to gender and development. Oxfam Publishing.

Poerwanto, \& Supraja, M. (2016). Model Ketahanan Pangan Berperspektif Gender (Gender Based Food Security Model). Dimensi Journal of Sociology, 9(2).

Quisumbing, A. R., Haddad, L., Meinzen-Dick, R., \& Brown, L. R. (1998). Gender Issues for Food Security in Developing Countries: Implications for Project Design and Implementation. Canadian Journal of Development Studies / Revue Canadienne d'études Du Développement, 19(4), 185-208. https://doi.org/10.1080/02255189.1998.9669784

Rachmat, M., \& Syakir, M. (2016). Kebijakan Pengembangan Diversifikasi Pangan dan Pangan Lokal (Food Diversification and Local Food Development Policy). In E. Pasandaran, R. Heriawan, \& M. Syakir (Eds.), Pangan Lokal: Budaya, Potensi dan Prospek Pengembangan (Local Food: 
Culture, Potential and Development Prospects). IAARD Press.

Rahardi, F. (2018). Globalisasi Pangan (Food Globalization). Kompas.

Sasmita, S. (2011). Peran Perempuan Suku Minangkabau yang Menjadi Kepala Keluarga (PEKKA) bagi Penciptaan Ketahanan Pangan Rumah Tangga di Kecamatan Padang Timur (The Role of Minangkabau Women Who Become Family Heads (PEKKA) for Achieving Household Food Security in Padang Ti. Humanus, 10(1). https://doi.org/https://doi.org/10.24036/jh.v10i1.489

Suharko. (2019). Preserving Corn Based-Local Food Culture: Case Study in Pagerejo Village, District of Wonosobo, Central Java. Sodality: Jurnal Sosiologi Pedesaan, 7(1), 57-64. https://doi.org/10.22500/sodality.v7i1.25458

Supriadi, H. (2005). Potensi, Kendala Dan Peluang Pengembangan Agroindustri Berbasis Pangan Lokal Ubikayu (Potential, Constraints and Opportunities for Local Cassava Based Agro-Industry Development). Center for Agricultural Economic and Policy Analysis, 103. http://ntb.litbang.pertanian.go.id/phocadownload/Prosiding/2007/7_Sosek.pdf

Suratiyah, K., Waluyati, L. R., \& Sari, P. N. (2013). Ketahanan Pangan dan Kemiskinan Rumah Tangga Petani di Kecamatan Paliyan Kabupaten Gunungkidul. In E. Rustiadi, Dadang, S. I. Aisyah, N. H. Arifin, M. Syukur, F. Williams, Suwardi, N. Nasrullah, \& Pudjianto (Eds.), Lokakarya Nasional dan Seminar: Forum Komunikasi Perguruan Tinggi Pertanian Indonesia (FKPTI). Fakultas Pertanian (Institut Pertanian Bogor).

Sutrisno, \& Edris, I. M. (2009). Reaktualisasi Diversifikasi Pangan Berbasis Sumber Daya Lokal (Reactualization of Local Resource-Based Food Diversification). Jurnal Pangan, 18(4), 45-58. https://doi.org/10.33964/jp.v18i4.218

Taridala, S. A. A., Harianto, Siregar, H., \& Hardinsyah. (2010). Analisis peran gender dalam pencapaian ketahanan pangan rumahtangga petani di kabupaten Konawe Selatan provinsi Sulawesi Tenggara. Thesis. Institut Pertanian Bogor. 